\title{
Critical Factors Affecting Oracle E-Business Suite Enterprise Resource planning (ERP) R12 Implementation: A Case Study of Saudi Arabia's University
}

\author{
Syed Zubair \\ Lecturer, Deanship of Information Technology, \\ Northern Border University, Kingdom of Saudi Arabia
}

\author{
Abu Taha Zamani \\ Lecturer, Deanship of Information Technology, \\ Northern Border University, Kingdom of Saudi \\ Arabia
}

the kingdom of Saudi Arabia has adopted of ERP. However, the ERP implementation is more expensive and complex. Thus, the difficulties and high failure rate in implementing ERP systems have been widely cited in the IT literature [9]. This research investigates the critical issues in ERP implementation in a developing country such as Saudi Arabia. The research examines the essential factors that enable or inhibit the success of ERP implementation. It uses this method of a case study to analysis these factors in terms of an Educational organizational performance and ERP capabilities and functions. A case study research method is preferred over field study research because it is focusing on the ERP system implementation within some real-life organizational context in the university subject of the case study.

\section{Literature Review}

Enterprise resource planning (ERP) is the process of business management software that allows an organization/firm to manage the business and office functions with the help of system of integrated applications. ERP software integrates all parts of entire operations, including planning, development, purchasing, inventory, manufacturing processes, sales and marketing. ERP software has a collection of modules of multiple enterprise software that are purchased, based on the best requirements of organization and its technical capabilities. Each and every ERP module is focused on different areas of organizational processes, such as Human capital, Finance, Supply Chain, Ware housing. An enterprise resource planning system is a packaged software system that enables an organization to manage the efficiently and effectively all the available resources. The evolution of ERP systems have been a highlighted in the information systems literature. Since early 2009 the literature suggests that ERP systems represent one of the most important categories of information technology in the last couple of decades. Although ERP has specific features, its application modules vary with different system providers such as (SAP, Oracle, PeopleSoft, JD Edwards, BAAN, and Navision). ERP modules can be classified as Finance (AP-Accounts Payable, GL-General Ledger, AR-Accounts Receivables, CM-Cash Management, FA-Fixed Assets), Manufacturing (WIP-Work in Progress, BOM-Bill of Materials), Distribution(OM-Order Management, PO-Purchase Order, INV-Inventory), Human Resource Management Systems(Pay Roll Advance benefits, Core HR), CRM(Tele Service, Field Service, Service Contracts). ERP systems as software packages composed of several modules providing a data integration through embedded business processes and programs across organizational functions and locations [12][16]. Unlike 
information systems an ERP system completely covers the reusable best business practices. Implementing an ERP requires business process reengineering, level of user acceptance, chain management, and technology innovation. Large number enterprises feel impelled by global competition to implement ERP systems but implementing an ERP system is neither cost effective nor risk free [23]. Consequently, fifty percent of global educational organizations have implemented ERP systems in some form with the growth of the ERP application market estimated at 37\% from 2002 to 2007 [22]. However, despite the high expectations that usually have ERP implementation they are blighted by over cost, delay in time and in some cases failure to implement the systems properly. Indeed, over $46 \%$ of ERP projects have been considered to be unsuccessful or do not achieve their expectations [13]. Common problems when implementing ERP systems occur because of various users' requirements factors and lack of integration between existing systems with ERP applications [14]. Organization should investigate the alignment between their needs and what an ERP system can do [20]. Furthermore, ERP adoption and usage remain a central concern to IT Managers. Even better advances in ERP capabilities and functions the troubling problems continue which leads to underutilized systems. Less (Low) usage of installed ERP systems has been identified as major challenging problems which are to be faced by organization management. Thus, along with an organizational transition to ERP, employees should be reeducated about the new system, must redefined their jobs; procedures are to be redesigned and processes rebuilding around core processes of the system ERP. ERP system implementations have been found to be very critical project to undertake and success is not guaranteed [19]. Mostly all ERP systems face implementation problems because of workers resistance [1]. One of the commonly cited reasons for ERP failures is end users reluctance to use the newly implemented ERP [17]. Hence, better understanding of end users acceptance/adoption of ERP systems is essential to make an ERP implementation a success [26]. The ERP system implementation may have been successful but end users often make use of a subset of available features [21]. In conclusion, end users acceptance level of ERP systems implementation remains a very complex, difficult to achieve yet extremely important phenomenon in the workplace. Thus, acquisition and implementation of ERP systems are very effort- intensive processes [6]. The literature on ERP contains many case studies of organizations that have a successful ERP system implementation and many other unable to achieve the least success [7]. The literature has also shown that despite of application and institutional problems the success of ERP implementation began with the adoptive use for end user, managers acceptance, and usage[28][4] [30][2][3]. Further, the culture in organizational has always been influence significantly on ERP implementation [24][10][5].

\section{Case Study}

A one of the reputed University in Kingdom of Saudi Arabia (X) was founded in 2007. In the beginning years, the institution's primary focus was on infrastructure, resources, international faculties, research professors and admission of students across the entire Kingdom of Saudi Arabia form almost all regions of the country. Then, in the early 2009's, it become famous and students from all over the kingdom is taking admission in the university, not only that a group of foreign students are admitted. Since then, the institution has expanded significantly, environmentally, functionally and technically in all the departments. The institution has conducted many national and international seminars and technical festivals. A huge crowd from the kingdom and across the kingdom attended and it becomes a grand successful. Meanwhile it was listed on top ten universities in the kingdom and earns a good name globally. In 2009 the organization expanded into the A class category of institution in the kingdom of Saudi Arabia. Therefore, the organization feels forced by global competition to acquire the Oracle EBusiness Suite ERP systems. It took two years for implementing ERP system, completes in 2011 with a cost of 5 Million SAR, the cost includes the software modified according to the users and organization requirements, 100 computer stations, cost of installation, and all the additional resources like (software, hardware, and accessories). The Oracle EBS Enterprise Resource Planning (ERP) system, which is a best management level system, was supposed to collect information from various key institutional processes like Human Resources, Purchasing, Financial, Inventory, and Warehouse and stores the data in a multiple comprehensive data repository which can be used by other processes of the organization. As an result of using the system, it was also believe to be the case that the information was previously divided into smaller division in different systems can smoothly in an uniform flow throughout the organization so that it can be distributed by different organizational processes in all the departments. But it is unfortunate that, the power or ability of the system were not utilized in an efficiently or in some cases never utilized. Table (1) shows report on the implemented functions related to the departments that the ERP system can offer and most of these functions were used or not. Moreover, the ERP system provides a decent function in the "Finance Department". Finance Department is the one on which the entire organization is depended; it connects with the "Warehouse Department" in production or formulation of resources to the employees, kiosks for institution for helping students in all the necessary needs. The "Purchase Department" even after having the capabilities with the ERP system uses a manual process and only the PO- Purchase Order module is under the usage. The "Information Technology" manager of X-Organization says: " $80 \%$ to $90 \%$ of mistakes occur in the production and formulations of departments are related to the "Human Resources", and there is a not usage in "Warehouse Department" as it is not implemented as per their requirements. Therefore, the elimination of errors in "Human Resources", adding an Inventory cycle process in "Purchase Department" for making the manual process into a system based, solving the issues related to "Finance Department", and most important the system for the "Warehouse/Stores Department" should be implemented effectively and efficiently. Table (1) shows report on the implemented functions related to the departments [32]. 


\begin{tabular}{|c|c|c|}
\hline Function & $\begin{array}{l}\text { Is the } \\
\text { functio } \\
\quad n \text { in } \\
\text { use(Yes } \\
\text { /No/Par } \\
\text { tial) }\end{array}$ & $\begin{array}{c}\text { Reason in case for } \\
\text { not use }\end{array}$ \\
\hline $\begin{array}{l}\text { Registration of } \\
\text { Employee on the ERP } \\
\text { system showing their } \\
\text { status. }\end{array}$ & Yes & \\
\hline $\begin{array}{l}\text { Recruitment of } \\
\text { Employee through the } \\
\text { system using } \\
\text { iRecruitment which is } \\
\text { the one of the } \\
\text { capability of Oracle E- } \\
\text { Business Suite R12. }\end{array}$ & No & $\begin{array}{l}\text { The system setup for } \\
\text { recruitment through } \\
\text { the system is not as } \\
\text { per the requirements } \\
\text { need to be } \\
\text { reimplementation or } \\
\text { huge customization. }\end{array}$ \\
\hline $\begin{array}{l}\text { Email notification } \\
\text { service }\end{array}$ & No & $\begin{array}{l}\text { Not in use because } \\
\text { the services are not } \\
\text { in Arabic and it's } \\
\text { not user friendly. }\end{array}$ \\
\hline $\begin{array}{lr}\text { Accessibility } & \text { for } \\
\text { Technical and } & \text { application developer }\end{array}$ & Partial & $\begin{array}{l}\text { Some of the form } \\
\text { and tables are } \\
\text { restricted against } \\
\text { update and oracle } \\
\text { does not encourage } \\
\text { customization which } \\
\text { is typical user } \\
\text { requirements. }\end{array}$ \\
\hline $\begin{array}{l}\text { When there is a } \\
\text { requirement of extra } \\
\text { resources } \\
\text { replacement of old } \\
\text { resources, the system } \\
\text { automatically alert the } \\
\text { Warehouse/purchase } \\
\text { departments }\end{array}$ & No & $\begin{array}{l}\text { As the system does } \\
\text { not have the } \\
\text { capability for the } \\
\text { warehouse (no } \\
\text { setup) and for } \\
\text { purchase there is no } \\
\text { cyclic integration } \\
\text { only Po-purchase } \\
\text { order is used. }\end{array}$ \\
\hline $\begin{array}{lr}\text { Credit of } & \text { salary } \\
\text { directly to employee } \\
\text { account } & \text { through } \\
\text { system(Online } & \text { Bank } \\
\text { Transfer) } & \end{array}$ & No & $\begin{array}{l}\text { The Oracle EBS } \\
\text { supports this service } \\
\text { but it is not } \\
\text { implemented or } \\
\text { never use in the } \\
\text { organization. }\end{array}$ \\
\hline $\begin{array}{l}\text { Employee can request } \\
\text { for leave using this } \\
\text { system }\end{array}$ & No & $\begin{array}{l}\text { This service is not } \\
\text { present or never } \\
\text { implemented so } \\
\text { organization have to } \\
\text { choose the process } \\
\text { of using paper. }\end{array}$ \\
\hline Payroll Service & Yes & $\begin{array}{l}\text { The payroll service } \\
\text { is used but only for } \\
\text { maintaining salary } \\
\text { records and no trust } \\
\text { on system in some } \\
\text { case because the } \\
\text { balance sheet does } \\
\text { not match with } \\
\text { actual salary }\end{array}$ \\
\hline
\end{tabular}

\begin{tabular}{|c|c|c|}
\hline & & statements. \\
\hline $\begin{array}{l}\text { Attendance service } \\
\text { through system }\end{array}$ & No & $\begin{array}{l}\text { This service is not } \\
\text { present or never } \\
\text { implemented. So a } \\
\text { new application } \\
\text { software is utilized. }\end{array}$ \\
\hline Deduction of Salary & Partial & $\begin{array}{l}\text { There is a major } \\
\text { issue in deduction of } \\
\text { salary as it continues } \\
\text { for throughout the } \\
\text { year even apply for } \\
\text { on monthly basis. }\end{array}$ \\
\hline $\begin{array}{l}\text { Erkab(Travelling } \\
\text { Allowance) }\end{array}$ & Yes & $\begin{array}{l}\text { As per user needs } \\
\text { some customization } \\
\text { and not directly } \\
\text { connected with } \\
\text { airline services and } \\
\text { manual entry of } \\
\text { payment records has } \\
\text { to be made. }\end{array}$ \\
\hline $\begin{array}{l}\text { Request on completion } \\
\text { of record for report } \\
\text { generation }\end{array}$ & Yes & $\begin{array}{l}\text { But number of new } \\
\text { reports to be added } \\
\text { and sometimes a } \\
\text { request pending } \\
\text { issue raised which is } \\
\text { due to more } \\
\text { consumption of } \\
\text { memory and not } \\
\text { automatic deletion } \\
\text { of unprocessed } \\
\text { unwanted requests. }\end{array}$ \\
\hline \begin{tabular}{ll} 
ERP & \multicolumn{2}{r}{ generated } \\
Balance sheet & match \\
with the actual \\
Balance sheet
\end{tabular} & No & $\begin{array}{l}\text { The Balance sheet } \\
\text { never matches with } \\
\text { the actual balance } \\
\text { sheet as a result } \\
\text { leads to manual } \\
\text { entry after a } \\
\text { completion } \\
\text { balance sheet on } \\
\text { paper. }\end{array}$ \\
\hline $\begin{array}{l}\text { User Friendly } \\
\text { (Human Computer } \\
\text { Interaction Standards) }\end{array}$ & Partial & $\begin{array}{l}\text { As it requires a } \\
\text { skilled user to } \\
\text { operate, so always } \\
\text { there is a risk of } \\
\text { modification by the } \\
\text { end user which leads } \\
\text { to critical errors. }\end{array}$ \\
\hline $\begin{array}{l}\text { Calendar in Both } \\
\text { English and Arabic }\end{array}$ & Yes & $\begin{array}{l}\text { The major problem } \\
\text { in this function is } \\
\text { the Hijri calendar } \\
\text { mismatch } \\
\text { Ummul with } \\
\text { calendar, Qura }\end{array}$ \\
\hline
\end{tabular}




\begin{tabular}{|c|c|c|}
\hline & & $\begin{array}{l}\text { leads to a addition } \\
\text { of a patch into the } \\
\text { database of the } \\
\text { system every year. }\end{array}$ \\
\hline iProcurement & No & $\begin{array}{l}\text { There is no usage of } \\
\text { it in the } \\
\text { organization. }\end{array}$ \\
\hline $\begin{array}{l}\text { Supply chain } \\
\text { management }\end{array}$ & No & $\begin{array}{l}\text { The organization } \\
\text { does not produce the } \\
\text { product to which } \\
\text { supply is applicable. }\end{array}$ \\
\hline Assets Inquiry & No & $\begin{array}{l}\text { No information to } \\
\text { user about the how } \\
\text { to use it. }\end{array}$ \\
\hline Bills of Materials & No & $\begin{array}{l}\text { No user knows the } \\
\text { information or the } \\
\text { managers does not } \\
\text { want to use it. }\end{array}$ \\
\hline $\begin{array}{ll}\text { Call Centre } & \text { Administration }\end{array}$ & No & $\begin{array}{l}\text { No Call Centre } \\
\text { service available or } \\
\text { requires } \\
\text { organization. }\end{array}$ \\
\hline $\begin{array}{l}\text { Language Translation } \\
\text { for complete forms }\end{array}$ & Partial & $\begin{array}{l}\text { There are still some } \\
\text { forms which does } \\
\text { not have a } \\
\text { translation from } \\
\text { Arabic to English or } \\
\text { vice versa. }\end{array}$ \\
\hline $\begin{array}{l}\text { Alerts user on leaving } \\
\text { a field blank }\end{array}$ & No & $\begin{array}{l}\text { The overall reports } \\
\text { in all departments } \\
\text { have some field } \\
\text { which is left blank. } \\
\text { That means the } \\
\text { users are ignoring to } \\
\text { make entry and the } \\
\text { system does not } \\
\text { have restrictions. }\end{array}$ \\
\hline $\begin{array}{l}\text { Email Centre } \\
\text { Administration/Client }\end{array}$ & No & $\begin{array}{l}\text { The organization is } \\
\text { not using the email } \\
\text { services provided by } \\
\text { the system. }\end{array}$ \\
\hline $\begin{array}{l}\text { Event and Seminars } \\
\text { (Oracle iProcurement) }\end{array}$ & No & $\begin{array}{l}\text { The organization } \\
\text { will conduct } \\
\text { seminars and events } \\
\text { on regular basis but } \\
\text { without any use of } \\
\text { ERP system as they } \\
\text { do not know the } \\
\text { service is available } \\
\text { and doesn't know its } \\
\text { functionality. }\end{array}$ \\
\hline $\begin{array}{l}\text { Human Resources } \\
\text { Intelligence }\end{array}$ & No & $\begin{array}{l}\text { The manager does } \\
\text { not want to add } \\
\text { anymore function } \\
\text { which increases the } \\
\text { complexity of the } \\
\text { system. }\end{array}$ \\
\hline
\end{tabular}

\begin{tabular}{|l|l|l|}
\hline $\begin{array}{l}\text { Integration between } \\
\text { departments }\end{array}$ & $\begin{array}{l}\text { The departments } \\
\text { make the report in } \\
\text { printed form and } \\
\text { give it to the consult } \\
\text { department } \\
\text { manually no usage } \\
\text { of system for } \\
\text { transferring of } \\
\text { information as there } \\
\text { is no connection } \\
\text { between modules of } \\
\text { system. }\end{array}$ \\
\hline
\end{tabular}

In spite of that all functions of the Oracle E-Business Suite ERP system related to the Warehouse and Stores Departments, of X-University are not in use. Moreover the portion of system or only some functions are in use in Human Resources, Finance, and Purchase Departments. ERP system in these department are completed setup but as per the Mangers in concern department comments that the system is near to zero or used for entering information manually and does not have trust on the report generated specially in Finance as the accounts does not match with actual balance sheet. Adding to what have been mentioned above, it's also important mention that most of the functions in the Supply Chain Management, and Human Resources modules are never used. The Information Technology department manager of XUniversity also comments:" It knows to me lately that the present information systems of the Finance, Purchase and Human Resources departments cannot be integrated with the Oracle EBS ERP system and this will result in many problems in the near future when we have to try to qualify the entire ERP system". Have been studied and tested the complete functions in every module available in the ERP system and the functions used, it can be concluded that maximum of $12 \%$ of the functions available were utilized, meaning that the company paid 23 Million SAR to invest only $12 \%$ of the cost which is only $27,600,000$ SAR and that a total of $202,400,000$ SAR is considered to be huge loss to the University. The HR manger comments and says:" The University has to paid even less than 500,000 SAR to the local vendor for the same functions which are using currently by EBS ERP system, another important thing he added is that we could have save a lot of time if the system have correctly implemented and utilized ". 


\section{Average Time to Implementation (Planned v. Actual)}

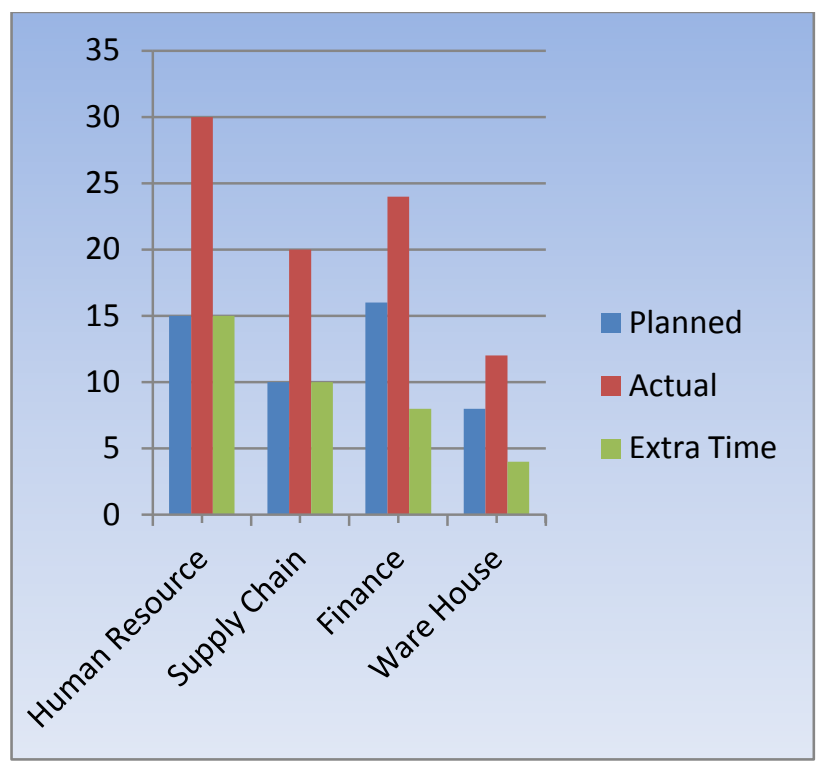

\section{Fig 1. Time taken for implementation of ERP system}

In the above Fig 1. $\mathrm{X}$-axis shows the Modules and $\mathrm{Y}$-axis shows the Months. In the present case study the time is extended beyond the planned time which is not acceptable and Oracle itself tells that the extended time is till 18 months, but the vendor had taken 30 months to complete the project.

\begin{tabular}{|l|l|}
\hline \multicolumn{2}{|c|}{ Reasons Behind Extended Durations } \\
\hline Initial Project Scope was Extended & $23 \%$ \\
\hline Organizational Issues & $15 \%$ \\
\hline Data Issues & $11 \%$ \\
\hline Resource Constraints & $25 \%$ \\
\hline Training Issues & $10 \%$ \\
\hline Technical Issues & $18 \%$ \\
\hline Conflicts in Priority of Project & $35 \%$ \\
\hline Unrealistic Timeline & $32 \%$ \\
\hline Vendor Functionality Issues & $22 \%$ \\
\hline
\end{tabular}

The above table (2) shows the reasons for extended time durations and the time increase due to its effects. The time extended to approximately $220 \%$ more than planned and $166 \%$ more than the oracle maximum extended limit.

\section{Conclusion and Findings}

This research output corresponds with expectations. The research shows that problems of the university management's approach of implementing Oracle E-Business Suite ERP, user's acceptance, believe in the reliability, work practice, and cultural behavior's all have impact on system usage directly and indirectly. The major reason for failure of the system is because of not giving importance to the software requirements specifications (SRS) while implementing the system for the users. Another main reason of ERP implementation failure to achieve the expected benefits is because the system is not under useful condition under some functions and is not completely accepted by end users. A basic need of every system that a subset of functions are used for one task by the users if among the subset any undefined or useless function involved leads to failure or incorrect result for the task. In addition to that, the big bang approach of implementing Oracle E-Business Suite ERP systems is not suitable to for the X-University educational organizational environment standards. The main mistakes in the case of the X-University can be summarized into the following points:

1. Not planned properly before the ERP implementation or unorganized planning is done that leads to Improper Planning which is the basic principle requirement of any system especially ERP.

2. Not correctly examined the ERP vendor.

3. The key features or capabilities of the Oracle E-Business Suite R12 are not understood properly or never used.

4. Not estimating correctly the time and resources required for the system.

5. From the beginning not to have a right professional on the team.

6. Priorities are not set properly.

7. Showing no interest or not investing in user training and change management.

8. The important of accurate data is underestimated and used the approximate or incorrect data.

9. Using all kind of different options or methods to solve problems or to achieve a goal.

10. Not withdrawing the legacy applications.

11. Cannot have a strategy for maintenance.

12. The employees are not familiar with such system as they are untrained, even the managers are afraid to deal with it at Functional level.

13. Failure of top management and IT department to recognize that effective use of ERP system requires strategic alignment between business and the system. Achieving alignment between ERP and business involves time, trust, effective relationship, user's acceptance strong, and support from top management as well as deep understanding of the strategic alignment maturity process.

14. The case-based research describes the lack of such an analysis and motivates the need for ERP system. Finally, the research contributes to ERP studies and practice by using explanatory case study research method.

\section{References}

[1] Aladwani Adel M. (2001). Change Management Strategies for Successful ERP Implementation, Business Process Management Journal, Vol. 7, No. 3.

[2] Allen, D. and T. Kern (2001). Enterprise Resource Planning Implementation: Stories of Power, Politics, and Resistance, in Proceedings of the IFIP working Group 8 -2 , Conference on Realigning Research and Practice in Information Systems Development: The Social and Organizational Perspective, Boise, Idaho, USA.

[3] Al-Mashari, M. (2002). Enterprise Resource Planning (ERP) Systems: A Research Agenda, Industrial Management \& Data Systems, Vol. 102, No. 3.

[4] Amoako - Gyampah, K. (2004). ERP Implementation Factors a Comparison of Managerial and End-User Perspectives, Business Process Management Journal.

[5] Beekhuyzen J. (2001). Organizational Culture and Enterprise Resource Planning (ERP) Systems Implementation. Honours Dissertation, School of 
Computing and Information Technology, Griffth University, Nathan, Brisbane, Australia.

[6] Bernroider Edward W.N. and Michel J. Leseure (2005). Enterprise Resource Planning (ERP) Diffusion and Characteristics According to the Systems Lifecycle: A Comparative View of Small - to Medium Sized and Large Enterprise, Vienna University of Economics and Business Administration, Vienna, August, Published Online by http://epub.wu-wien.ac.at.

[7] Bhatti T.R. (2005). Critical Success Factors for the Implementation of Enterprise Resource Planning (ERP): Empirical Validation, the second International Conference on Innovation in Information Technology, Zayed University, College of Business, Dubai, UAE.

[8] Chin Chen-wen et al (2007). An Empirical Study on the correlation Between ERP Knowledge Management Implementation and Enterprise operating performance in Taiwan's Industries, International Journal of the Computer, the Internet and Management, Vol. 15.

[9] Davenport, T.H. (1998). Putting the Enterprise into the Enterprise System, Harvard Business Review.

[10] Davis, C.H. (2004). Perceived Effects of ERP on Jobs and Work in a Contact Centre. Proceedings of the International Conference on work with computer systems, Kula Lampur, April 4.

[11] Esteves J.M. and A.J. Pastor (2001). Enterprise Resource Planning Research: An Annotated Bibliography, Communications of the Association for Information Systems.

[12] Haines, M.N. \& Goodhue, D.L. (2003). Implementing Partner Involvement and Knowledge Transfer in the context of ERP Implementation, International Journal of Human Computer Interaction, 16.

[13] Holsapple Clyde W., et al. (2005). Empirically Testing User Characteristics and Fitness Factors in Enterprise Resource Planning success, International Journal of Human IJCSNS International Journal of Computer Science and Network Security, VOL.9 No.4, April 2009 363- Computer Interaction, 19 (3). Lawrence Erlbaum Associates, Inc.

[14] Kalbasi Houman (2007). Assessing ERP Implementation Critical Success factors ( a Case Based Study), Masters Thesis, Tarbiat Modares University, Faculty of Engineering, Department of Industrial Engineering.

[15] Lin.W.T. et al (2006). A study on performance of Introducing ERP to Semiconductor Related Industries in Taiwan, Springer -Verlag.

[16] Nah Hoon - Fiona Fui, et al. (2003) ERP Implementation: Chief Information Officers Perceptions of Critical Success Factors, International Journal of Human - computer interaction, 16 (1), Lawrence Eribaum Associates, Inc.

[17] Nah Hoon- Fiona Fui, et al . (2006) Toward a Greater Understanding of End- User's Acceptance of ERP systems /in/ Advanced Topics in Information Resources Management, edited by Mehdi. Kosrow- Pour, Vol. 5, Idea Group Publishing.

[18] Nah, F.F., Lau, J.L. and Kuang, J. (2001). Critical Factors for Successful Implementation of Enterprise Systems, Business Process Management, 7 (3).

[19] Nielsen Jens Laurits (2002). Critical Success Factors For Implementing An ERP System in A University Environment: A Case Study from the Australian HES, Faculty of Engineering and Information Technology, Griffith University.

[20] O'Leary Daniel E. (2004). Enterprise Resource Planning (ERP) systems: An Empirical Analysis of Benefits, Journal of emerging Technologies in Accounting, Vol. 1.

[21] Seymour Lisa, et al. (2007). End-Users Acceptance of Enterprise Resource Planning Systems: An Investigation of Antecedents, Proceedings of the 6th Annual ISONE world Conference, April, Las Vegas, NV. Available at http://www.isoneworld.org.

[22] Shepherd Craig (2006). Constructing Enterprise Resource Planning: A Thoroughgoing Interpretivisit Perspective on Technological Change, Journal of Occupational and Organizational Psychology, The British Psychological Society (79).

[23] Shih Ya- Yueh (2006). The Effect of Computer Self Efficacy on Enterprise Resource Planning Usage, Behavior \& Information Technology, Vol. 25, No. 5, September - October.

[24] Soh, C., Kien, S.S., and Tay-Yap, J. (2000). Cultural Fits and Misfits: Is ERP a Universal Solution?, Communications of the ACM, 43 (4).

[25] Thavapragasam Xavier Thararuban (2003). Cultural Influences on ERP Implementation Success, Proceedings of the first Undergraduate Students Computing Conference, Griffith University, Nathan , Brisbane , Australia.

[26] Umble, E.J., and Umble, M.M. (2002). Avoid ERP Implementation Failure. Industrial Management, 44 (1).

[27] Venkatesh Viswanth and Fred D. Davis (2000). A Theoretical Extension of the Technology Acceptance Model: Four Longitudinal Field Studies, Management Science, Vol. 46, No. 2, February.

[28] Wah, L. (2000). Give ERP a chance. Management Review, 89(3).

[29] Yingjie Jiang (2005). Critical success Factors in ERP Implementation in Finland, M.Sc. Thesis in Accounting, the Swedish school of Economics and Business Administration.

[30] Zviran, M., Pliskin, N. and Levin, R. (2005) Measuring User Satisfaction and Perceived Usefulness in the ERP Context, Journal of computer Information Systems, 45 (3). 
[31] Financial Consolidation and Reporting Applications: Adding Value to Enterprise Resource Planning Applications. http://www.oracle.com/us/ccentral/financial-consolidation-1887321.pdf
[32] Critical Factors Affecting Enterprise Resource Planning Implementation: An Explanatory Case Study by Saad Ghaleb Yaseen, Department of Management Information Systems, Al-Zaytoonah University of Jordan, published in IJCSNS International Journal of Computer Science and Network Security, VOL.9 No.4, April 2009. 